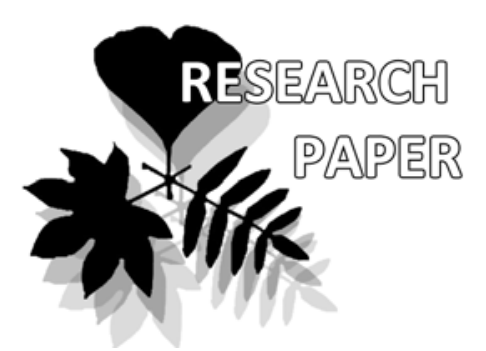

\title{
Anti-lipoxygenase, radical scavenging and antimicrobial activities of lichen species of genus Heterodermia (Physciaceae)
}

Bhaskar C. Behera*

e-mail: bcbehera2002@yahoo.co.in

Mangesh V. Morey

e-mail: mangeshbiotech@gmail.com

Subhash B. Gaikwad

e-mail: subhashkyk@gmail.com

* corresponding author

Agharkar Research Institute, G.G. Agarkar Road, Pune - 411004, India

Manuscript received: 06.08 .2014

Review completed: 20.09.2015

Accepted for publication: 02.10.2015

Published online: 06.11.2015
Bhaskar C. Behera*, Mangesh V. Morey \& Subhash B. Gaikwad

\begin{abstract}
A B S T R A C T
The aim of the research is to explore antilipoxygenase, radical scavenging and antimicrobial activity of the ethyl acetate extract of the selected lichen species of genus Heterodermia (Physciaceae). The species extract have shown concentration dependent lipoxygenase (LOX) inhibition. Fifty percent $\left(\mathrm{IC}_{50}\right)$ LOX inhibition was obtained by $H$. diademata, $H$. flabellata, $H$. antillarum and $H$. incana with 0.123 , $0.153,0.160,0.150 \mathrm{mg} / \mathrm{ml}$ respectively; which is smaller than the synthetic antioxidant BHA and BHT. Only the extract of $H$. diademata showed $\mathrm{IC}_{50}, 0.123$ $\mathrm{mg} / \mathrm{ml}$ is equal to LOX inhibitor Indomethicin. The LOX inhibition kinetics with respect to the lichen extract resulted different mode of inhibition. Competitive inhibition was found towards LOX by $H$. albicans, $H$. antillarum; uncompetitive inhibition by $H$. diademata and noncompetitive inhibition showed by $H$. angustiloba, $H$. flabellata, $H$. incana, H. isidiophora and $H$. psendospeciosa. These species extract have also showed $\leq 50 \%$ radical scavenging activity. The ethyl acetate extract of $H$. diademata, $H$. angustiloba, $H$. albicans and $H$. isidiophora showed the strong antimicrobial activity against most of the tested microorganisms at concentration ranging from $0.232 \mathrm{mg} / \mathrm{ml}$ to $0.591 \mathrm{mg} / \mathrm{ml}$. These findings suggest that these lichen species of genus Heterodermia can be used as new bioresources for the natural lipoxygenase inhibitor with antimicrobial and radical scavenging features.

K e y w o r d s : Heterodermia, lipoxygenase inhibition, antioxidant, antimicrobial activity
\end{abstract}

\section{P E 3 Ю M E}

БехераБ.С.,МориМ.В.,ГайкваАС.Б.Антилипоксигеназа,радикальная очистка и антимикробная активность мишайников рода Heterodermia (Physciaceae). Цель исследования - антилипоксигеназа, радикальная очистка и антимикробная активность этилацетатного экстракта виАов Аишайников рода Heterodermia (Physciaceae). Экстрактам видов рода свойсвенно мипоксигеназное ингибирование (LOX), зависящее от концентрации. Пятилесятипроцентное $\left(\mathrm{IC}_{50}\right)$ ингибирование LOX отмечалось у вилов H. diademata, $H$. flabellata, $H$. antillarum и H. incana при концентрациях 0,123 0,153, 0,160 и 0,150 мг/м соответственно; что меньше, чем у синтетических антиоксиАантов ВНА и ВНТ. Только экстракт $H$. diademata показал $\mathrm{IC}_{50}$ при концентрации 0,123 мг/м^ равным LOX ингибитора индометацин. Кинетика LOX ингибирования экстрактов разных виАов Аишайников показывает разный режим ингибирования. Конкурентное ингибирование LOX отмечено у $H$. albicans и $H$. antillarum; неконкурентое - у $H$. diademata; отсутствие конкуренции характерно м^я $H$. angustiloba, $H$. flabellata, H. incana, H. isidiophora и H. pseudospeciosa. Экстракты этих видов также показами пятиАесятипроцентную активность радикальной очистки. Этилацетатные экстракты $H$. diademata, $H$. angustiloba, $H$. albicans и $H$. isidiophora показали сильную антимикробную активность в отношении большинства протестированных микроорганизмов в концентрациях от 0,232 до 0,591 мг/мк. Результаты показывают, что вилы мишайников Heterodermia могут быть использованы в качестве нового биоресурса природной мипоксигеназы с антимикробными и очистительными свойствами.

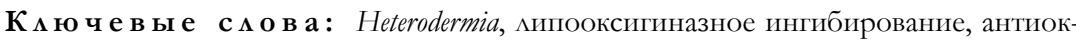
сидант, антимикробная активность

Переведено редколмегией

\section{INTRODUCTION}

Lipoxygenase (Linoleate: oxygen 13-oxidoreductase, EC 1.13.11.12) (LOX) is widely distributed in nature and is found in all plants and animals (Serpen \& Gokmen 2007). LOX catalyzes the oxidation of poly unsaturated fatty acids and forming hydroperoxides. The products of the degradation of poly unsaturated fatty acids and their derivatives can react with proteins, peptides, and amino acids; which can result in off-flavour production and rancidity of oils thereby lowering nutritional values of oil-based foods (Iassonova et al. 2009). Hence LOX is the main enzyme in offflavor development. It is one of the most important quality parameters in foods. LOXs are important for food stuff and are also important in medical applications. LOX has 
been implicated in the progression of certain cancers and health disorders (Kelvakar et al. 2000, 2001). Furthermore, the products of LOX catalyzed oxygenation [hydro peroxy eicosa tetra enoic acid (HPETE), hydroxyl eicosa tetra enoic acid (HETE), Leukotrines and Lipoxins) apparently are involved in the development of rheumatoid, arthritis, psoriasis, asthmatic responses (Sircar et al. 1983). LOX are sensitive to antioxidants as antioxidants are involved in inhibition of lipid hydroperoxide formation due to scavenging of lipidoxy- or lipidperoxy-radicals. This could lead to less availability of lipid hydroperoxide substrate required for LOX catalysis (Rakova et al. 2007).

Synthetic antioxidants Butylated Hydroxy Toluene (BHT) and Butylated Hydroxy Anisol (BHA) use as additives in food are efficient LOX inhibitors. However, their use is being restricted because of their possible toxic and carcinogenic effects (Barlow 1990). Recently, there is a great interest in substituting them with natural LOX inhibitors.

Bacterial resistance to antibiotics is becoming an increasing problem world wide. Due to risk of adverse effects encountered with the use of synthetic antibiotics, plants or other organisms may offer an alternative source for antimicrobial agent with significant activity against pathogenic and infective microorganisms. Natural products derived from these sources offer a new source of biologicals that may have a great impact on infectious disease and over all human health (Balandrin et al. 1985, Conner 1993, Govindappa 2011).

Natural products with diverse bioactivities are an important source of novel chemicals. Pharmaceutical industry is forced to continuous search and development of new pharmacological active molecules. Similar to higher plants, lichens are considered as potential source of novel biologically active compounds. Lichens are complex symbiotic associations between a fungus (mycobiont) and an alga (photobiont) with unique characteristics in plant kingdom. They are proven as the earliest colonizers of terrestrial habitats on the earth with a worldwide distribution from tropical to alpine and from the plains to the highest mountains (Taylor et al. 1995, Mitrovic et al. 2011). Lichens produces unique secondary metabolites, known as lichen substances are mostly small, but complex molecules. Structures for more than 1050 different lichen substances have been reported to date (Molnar \& Farkas 2010, Stocker-Worgotter 2008). The lichen substances and lichen extracts exert a remarkable variety of biological effects; antibacterial, antiviral, antifungal, antiprotozoal, antiherbivore, antimutagenic, antioxidant, antitumor, antiulcerogenic, antinociceptive, antipyretic, anti-inflammatory, anti-proliferative and cytotoxic effects, cardiovascular protective, glucosidase inhibitory and probiotic stimulating activities (Muller 2001, Behera et al. 2005a,b, 2012, Rankovic 2007, Verma et al. 2011, 2012, Mahadik et al. 2011, Manojlovic et al. 2012, Gaikwad et al. 2014). Despite of these manifold activities of lichen metabolites been recognized, their therapeutic potential has not yet been fully explored and thus remains pharmaceutically unexploited (Crittenden \& Porter 1991).

Therefore the objective of the study is to explore antilipoxygenase, antimicrobial, and antioxidant activity of the some of the lichen species of genus Heterodermia of family Physciaceae.

\section{MATERIALS AND METHODS Study material}

Lichens species of genus Heterodermia (Physciaceae) were collected from different parts of Western ghats of India (Fig. 1). The identification of the species was done in the laboratory on the basis of morphological, anatomical and chemical characteristics. The presence of major lichen substances in the species was identified using Thin Layer Chromatography method described by Culberson \& Kristinsson (1972). Heterodermia albicans voucher no. AMH-99.306 producing Atranorin, Zeorin, Salazinic acid; $H$. angustiloba voucher no. AMH-78.80 producing Atranorin, Zeorin, Norstictic, Salazinic acid; $H$. antillarum voucher no. AMH-74.1138 producing Atranorin, Zeorin, Salazinic acid and unknown substances; $H$. diademata voucher no. AMH-04.118 producing Atranorin, Zeorin, Chloroatranorin; H. flabellata voucher no. AMH-74.1194 producing Atranorin, Zeorin and unknown yellow pigment; $H$. incana voucher no. AMH-77.299 producing Atranorin, Zeorin; H. isidiophora voucher no. AMH-99.342 producing Atranorin, Zeorin; H. pseudospeciosa voucher no. AMH-04.170 producing Atranorin, Zeorin, Norstictic, Salazinic acid. The materials are deposited in Ajrekar Mycological Herbarium $(\mathrm{AMH})$ at Agharkar Research Institute, Pune, India. Lichen specimens of Heterodermia producing biological active secondary compounds with their class is presented in Table 1.

Bacterial and fungal cultures were obtained from the National Collection of Industrial Microorganisms (NCIM), National Chemical Laboratory, Pune, India. These bacterial cultures are namely Bacillus subtilis (NCIM 2063), Streptococcus faecalis (NCIM 5024), Candida albicans (NCIM 3471) and Cryptococcus albidus var. diffluens (NCIM 3371) were tested against lichen extract to ascertain their antimicrobial activity.

\section{Extraction of lichens compounds}

Eight lichen species Heterodermia albicans, $H$. angustiloba, $H$. antillarum, $H$. diademata, $H$. flabellata, $H$. incana, H. isidiophora and $H$. pseudospeciosa were selected for the study for different experiments. Approximately $300 \mathrm{mg}$ biomass of each dry natural lichen thallus were extracted through soxhlet apparatus with solvent ethyl acetate. Extracting period was 72 hours at room temperature. Then these extracted compounds of the above mentioned lichens were weighed. Then this extract of each lichen thallus was taken and used in the testing of antilipoxygenase, antimicrobial and antioxidant activities.

\section{Lipoxygenase inhibition assay}

Lipoxygenase inhibition of lichen extracts were evaluated with the spectrophotometer methodology described by Shinde at al. (1999) and Theerakulkait \& Barrett (1995), with minor modifications. The substrate solution was prepared by mixing $25 \mu \mathrm{l}$ of pure linoleic acid and $15 \mathrm{ml}$ of $0.1 \mathrm{M}$ sodium borate buffer at $\mathrm{pH}$ 9.0. The solution was made transparent by adding $0.15 \mathrm{ml}$ of $0.1 \mathrm{~N} \mathrm{NaOH}$ and diluting to $25 \mathrm{ml}$ with $0.1 \mathrm{M}$ sodium borate buffer at $\mathrm{pH} 9.0$ to a final concentration of $3 \mathrm{mM}$ linoleic acid. The reaction mixture was then prepared which consisted of $3.0 \mathrm{ml}$ of substrate solution with $0.15 \mathrm{ml}$ of lichen extract concentra- 
tion $(5,40,80,120,200 \mu \mathrm{g} / \mathrm{ml})$ and then 0.05 $\mathrm{ml}$ of LOX solution (20000 U ml-1) was added and incubated for 5 minutes at room temperature. The absorbance at $234 \mathrm{~nm}$ was recorded on a UV-Vis spectrophotometer (Shimadzu-1601 PC). The percentage LOX inhibition was calculated by the following equation:

\section{$\%$ of inhibition $=\frac{\text { Absorbance of control-Absorbance of test }}{\text { Absorbance of control }} \times 100$}

\section{Lipoxygenase inhibition kinetics}

The LOX inhibition kinetics was analysed by Lineweaver-Burk plot with inhibitor lichen extract concentration $(10,30,90,180 \mu \mathrm{g} / \mathrm{ml})$. Reaction mixture without extract was used as negative control.

\section{Antioxidant assay}

Antioxidative activity of eight lichen species of genus Heterodermia were determined in terms of free radical scavenging (DPPH) following the methodology described by Blois (1958) and for trolox equivalent activity capacity (TEAC) following by Miller et al. (1995). The detailed descriptions with minor modifications of the procedure for these antioxidative assays were reported in our previous papers (Verma et al. 2008, Behera et al. 2005). Synthetic antioxidant Butylate Hydroxy Anisol (BHA) and Butylate Hydroxy Toluene (BHT), Trolox (water soluble vitamin $\mathrm{E}$ analogue) were used as positive standard compound for comparison with lichen extracts antioxidant activity.

\section{Calculation of $50 \%$ inhibition concentration $\left(\mathrm{IC}_{50}\right)$}

$\mathrm{IC}_{50}$ value of the lichen extract and the standard compound BHA, BHT and Indomethicin for the $50 \%$ lipoxygenase inhibition were calculated by extrapolation from concentration/effect regression line obtained from different concentrations $(5,40,80,120,200 \mu \mathrm{g} / \mathrm{ml})$.

\section{Antimicrobial assay}

Antimicrobial potential of eight lichen species of Heterodermia genus were determined by standard disk diffusion method approved by the National Committee for Clinical Laboratory Standards (NCCLS, 1993), and Minimum Inhibitory Concentration (MIC) of lichen extract were determined with the help of method described by Rankovik et al. (2007). Erythromycin, Tetracyclin, Streptomycin were used as positive control. The details of the procedure were described earlier in our previous report (Mahadik et al. 2011).

All chemical reagents used in the assays carried out were of analytical grade obtained from different agencies; e.g. Sigma (USA), Hi-media, Qualigens (India).
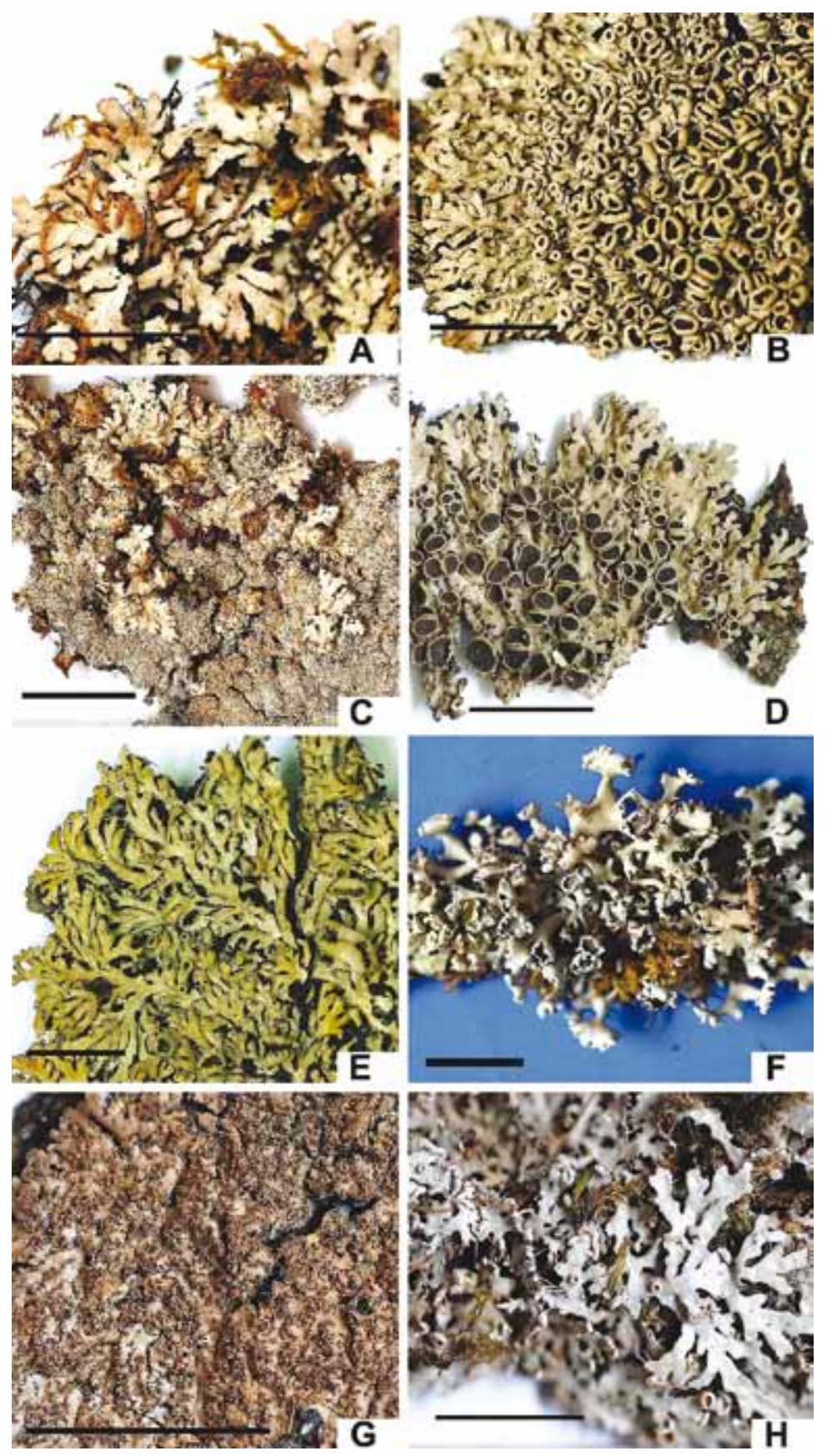

Figure 1 Natural thalli of lichens: A: Heterodermia albicans, B: H. angustiloba, C: H. antillarum, D: H. diademata, E: H. flabellata, F: H. incana, G: H. isidiophora, $\mathrm{H}: H$. pseudospeciosa (scale $=10 \mathrm{~mm}$ )

\section{RESULTS AND DISCUSSION}

Lipoxygenase (LOX) inhibition by the extract of eight lichen species of genus Heterodermia was studied. The inhibition of LOX by the ethyl acetate extract of lichen species are presented in Table 2. All the species extract have shown increasing trend in LOX inhibition, when the extract concentration increased from 5.0 to $200 \mu \mathrm{g} / \mathrm{ml}$. This result indicated that the LOX inhibition is inhibitor concentration dependent. However, variation in LOX inhibition was found among the species with respect to the extract concentration. $H$. diademata and $H$. albicans showed LOX inhibition between $69.2 \%$ and $86.64 \%$ at extract concentration between 120 
Table 1. Lichen specimens producing biological active secondary compounds with their class

\begin{tabular}{ll}
\hline Lichen species & Compounds with Class \\
\hline Heterodermia albicans & Atranorin: Depsides \\
& Salazinic acid: Depsidones \\
& Zeorin: Terpenoid \\
Heterodermia angustiloba & Atranorin: Depsides \\
& Norstictic acid: Depsidones \\
& Salazinic acid: Depsidones \\
& Zeorin: Terpenoid \\
Heterodermia antillarum & Atranorin: Depsides \\
& Salazinic acid: Depsidones \\
& Zeorin: Terpenoid \\
Heterodermia diademata & Atranorin: Depsides \\
& Chloroatranorin: Depsides \\
Heterodermia flabellata & Zeorin: Terpenoid \\
& Atranorin: Depsides \\
Heterodermia incana & Zeorin: Terpenoid \\
& Atranorin: Depsides \\
Heterodermia isidiophora & Zeorin: Terpenoid \\
& Atranorin: Depsides \\
Heterodermia pseudospeciosa & Zeorin: Terpenoid \\
& Atranorin: Depsides \\
& Norstictic acid: Depsidones \\
& Salazinic acid: Depsidones \\
& Zeorin: Terpenoid \\
\hline
\end{tabular}

and $200 \mu \mathrm{g} / \mathrm{ml}$. H. angustiloba, H. antillarum and H. incana varies from 52.11 to $62.32 \%$ at 120 to $200 \mu \mathrm{g} / \mathrm{ml}$ extract. Other species showed upto $43 \%$ LOX inhibition even at higher concentration of extract at $200 \mu \mathrm{g} / \mathrm{ml}$. Indomethicin a standard LOX inhibitor had from $72.64 \%$ to $81.13 \%$ LOX inhibition at concentration range between 80 and $200 \mu \mathrm{g} /$ $\mathrm{ml}$. Comparing with the species extract and with the standard inhibitor, $H$. diademata and $H$. albicans showed LOX inhibition are equivalent to the Indomethicin at $200 \mu \mathrm{g} / \mathrm{ml}$ conc. $75 \%$ to nearly $80 \%$ LOX inhibition was achieved by synthetic antioxidant BHA and BHT at the same concentration. As far as $\mathrm{IC}_{50}$ value of the lichen extract for $50 \%$ LOX inhibition is concerned, the $\mathrm{IC}_{50}$ value of $H$. diademata, $H$. flabellata, $H$. antillarum, $H$. incana are found $0.123,0.153$, $0.160,0.150 \mathrm{mg} / \mathrm{ml}$ respectively. The $\mathrm{IC}_{50}$ value of the mentioned species are found less than the standard antioxidant BHA $(0.198 \mathrm{mg} / \mathrm{ml})$ and BHT $(0.186 \mathrm{mg} / \mathrm{ml})$. Only $\mathrm{IC}_{50}$ value of $H$. diademata was found to be equal to $\mathrm{IC}_{50}$ of Indomethicin (Table 3).

We have further investigated the lipoxygenase inhibition kinetics with respect to the various lichen species extract analyzing by lineweaver burk plot. The $\mathrm{Km}$ and Vmax value obtained by lichen extract as inhibitor against LOX are presented in Table 4. The lichen extract concentration as inhibitor used were $10,30,90$ or $180 \mu \mathrm{g} / \mathrm{ml}$. Linoleic acid concentration $0.2,0.5,1.0,2.5 \mathrm{mg} / \mathrm{ml}$ used as substrate. Without lichen extract was used as -ve control. H. antillarum extract at low concentration $(10 \mu \mathrm{g} / \mathrm{ml})$ showed $\mathrm{Km}$ $3.75 \mu \mathrm{M}$ with $\mathrm{V} \max 5.263 \mu \mathrm{mol} / \mathrm{min}$. Increased concentration of $H$. diademata extract showed the $\mathrm{Km}$ value ranging from $0.227 \mu \mathrm{M}$ to $0.43 \mu \mathrm{M}$ with a Vmax up to $1.01 \mu \mathrm{Mol} /$ min. H. angustiloba, had Vmax $5.0 \mu \mathrm{Mol} / \mathrm{min}$ only at extract concentration of $10 \mu \mathrm{g}$ and at higher concentration decreasing trend in $\mathrm{Vmax}$ and inconsistent $\mathrm{Km}$ value was obtained. $H$. albicans followed the same trend with respect to $\mathrm{Km}$
Table 2. Lipoxygenase inhibition by the ethyl acetate extracts concentration of various species of Heterodermia genus of lichen family Physciaceae. The values presented are mean of 3 consecutive reading of the assay in every five minute interval

\begin{tabular}{lccccc}
\hline & \multicolumn{5}{c}{ Extract concentration $\left(\boldsymbol{\mu g} . \mathbf{m l}^{-1}\right)$} \\
\cline { 2 - 6 } Lichen species & $\mathbf{5}$ & $\mathbf{4 0}$ & $\mathbf{8 0}$ & $\mathbf{1 2 0}$ & $\mathbf{2 0 0}$ \\
\cline { 2 - 6 } & 7.0 & 38.5 & 47.86 & 69.2 & 86.64 \\
\hline H. diademata & 11.75 & 38.31 & 47.04 & 52.49 & 53.44 \\
H. angustiloba & 9.2 & 28.76 & 52.33 & 77.39 & 85.44 \\
H. albicans & 2.7 & 19.57 & 27.44 & 38.78 & 65.17 \\
H. flabellata & 6.18 & 21.57 & 36.02 & 58.77 & 62.14 \\
H. antillarum & 11.23 & 28.16 & 36.52 & 39.27 & 43.64 \\
H. isidiophora & 2.42 & 13.78 & 33.26 & 52.11 & 66.32 \\
H. incana & 5.2 & 14.28 & 21.44 & 37.51 & 43.09 \\
H.pseudospeciosa & 5.20 & & & \\
Standard antioxidant & & & & \\
BHA & 23.44 & 37.53 & 48.16 & 63.79 & 79.42 \\
BHT & 16.33 & 29.04 & 53.17 & 60.08 & 74.52 \\
\hline Standard lipoxygenase inhibitor & & & \\
Indomethicin & 10.44 & 23.51 & 72.64 & 75.27 & 81.13 \\
\hline \multicolumn{7}{c}{}
\end{tabular}

Table 3. $\mathrm{IC}_{50}$ value of lichen species extract for $50 \%$ lipoxygenase inhibition. Determination of antioxidant activity in terms of TEAC and DPPH free radical of the lichen extract carried out with $100 \mu \mathrm{l}$ of $1 \mathrm{mg}$ extract / $\mathrm{ml}$ was used. TEAC value is expressed as $\mathrm{mM}$ of Trolox solution having the antioxidant equivalent to a $0.1 \%(\mathrm{w} / \mathrm{v})$ extract solution. The values presented are mean of the 3 consecutive reading of the assay in every five minute interval

\begin{tabular}{lccc}
\hline Lichen Species & $\begin{array}{c}\text { Lipoxygenase } \\
\text { inhibition } \\
\text { IC }\end{array}$ & \multicolumn{2}{c}{ Antioxidant activity } \\
\cline { 3 - 4 } (m)/ml) & $\begin{array}{c}\text { TEAC } \\
\text { (mM) }\end{array}$ & $\begin{array}{c}\text { DPPH } \\
\text { (\% inhibi- } \\
\text { tion) }\end{array}$ \\
\hline H. diademata & 0.123 & 11.9 & 44.47 \\
H. angustiloba & 0.187 & 12.36 & 39.29 \\
H. albicans & 0.187 & 12.56 & 37.33 \\
H. flabellata & 0.153 & 12.96 & 36.35 \\
H. antillarum & 0.160 & 11.96 & 31.65 \\
H. isidiophora & 0.229 & 12.92 & 25.92 \\
H. incana & 0.150 & 12.78 & 21.56 \\
H. psendospeciosa & 0.232 & 12.9 & 51.77 \\
\hline Standard antioxidant & & & \\
BHA & 0.198 & - & 84.72 \\
BHT & 0.186 & - & 83.49 \\
Trolox & - & 3.77 & - \\
\hline Lipoxygenase inhibitor & & \\
Indomethacin & 0.123 & - & - \\
\hline
\end{tabular}

value, but $V \max 1.667 \mu \mathrm{Mol} / \mathrm{min}$ was obtained at extract concentration $90 \mu \mathrm{g} / \mathrm{ml}$, beyond that $\mathrm{Vmax}$ was decreased. $H$. incana showed equal value in $\mathrm{Km}(2.5)$ and $V \max 2.5$ $\mu \mathrm{mol} / \mathrm{min}$ at $30 \mu \mathrm{g}$ extract. H. flabellata had no significant increase in $\mathrm{Km}$ and Vmax value even after increasing the extract concentration up to $180 \mu \mathrm{g} H$. isidiophora, H. psendospeciosa followed the same trend with respect to their $\mathrm{Km}$ and Vmax as observed in $H$. flabellata. The results suggest that extract concentration beyond $30 \mu \mathrm{g} / \mathrm{ml}$ acts as antagonistic effects on lipoxygenase inhibition.

Antioxidative activity in terms of Trolox Equivalent Antioxidant Capacity (TEAC) and scavenging of DPPH 
Table 4. The kinetics for lipoxygenase reaction $\mathrm{Km}$ and Vmax was determined using Lineweaver-Burk plot. Linoleic acid as substrate $(0.2,0.5,1.0,2.5 \mathrm{mg} / \mathrm{ml})$ was used with various concentration of extract $(10,30,90 \mathrm{or} 180 \mu \mathrm{g} / \mathrm{ml})$ of different species of lichen genus Heterodermia

\begin{tabular}{|c|c|c|c|c|c|c|c|c|c|c|}
\hline \multirow[t]{2}{*}{ Lichen species } & \multicolumn{2}{|r|}{0} & \multicolumn{2}{|c|}{$10 \mu \mathrm{g}$} & \multicolumn{2}{|c|}{$30 \mu \mathrm{g}$} & \multicolumn{2}{|c|}{$90 \mu \mathrm{g}$} & \multicolumn{2}{|c|}{$180 \mu \mathrm{g}$} \\
\hline & $\begin{array}{c}\mathrm{Km} \\
(\mu \mathrm{M})\end{array}$ & $\begin{array}{c}\text { Vmax } \\
(\mu \mathrm{mol} / \mathrm{min})\end{array}$ & $\begin{array}{c}\mathrm{Km} \\
(\mu \mathrm{M})\end{array}$ & $\begin{array}{c}\text { Vmax } \\
(\mu \mathrm{mol} / \\
\mathrm{min})\end{array}$ & $\begin{array}{c}\mathrm{Km} \\
(\mu \mathrm{M})\end{array}$ & $\begin{array}{c}\text { Vmax } \\
(\mu \mathrm{mol} / \\
\mathrm{min})\end{array}$ & $\begin{array}{c}\mathrm{Km} \\
(\mu \mathrm{M})\end{array}$ & $\begin{array}{c}\text { Vmax } \\
(\mu \mathrm{mol} / \mathrm{min})\end{array}$ & $\begin{array}{c}\mathrm{Km} \\
(\mu \mathrm{M})\end{array}$ & $\begin{array}{c}\text { Vmax } \\
(\mu \mathrm{mol} / \\
\mathrm{min})\end{array}$ \\
\hline H. didemata & 0.4 & 0.625 & 0.227 & 4.0 & 0.4 & 4.0 & 0.4 & 1.01 & 0.435 & 0.909 \\
\hline H. anguistiloba & 0.4 & 0.625 & 0.44 & 5.0 & 0.385 & 1.25 & 0.444 & 0.741 & 0.345 & 0.476 \\
\hline H. albicans & 0.4 & 0.625 & 0.526 & - & 0.333 & 1.333 & 0.588 & 1.667 & 0.455 & 0.769 \\
\hline H. flabellate & 0.625 & 0.625 & 0.625 & 1.25 & 0.5 & 0.833 & 0.529 & 0.8 & 0.714 & 0.833 \\
\hline H. antillarum & 0.625 & 0.625 & 3.751 & 5.263 & 0.667 & 1.429 & 0.588 & 1.0 & 0.455 & 0.667 \\
\hline H. isidiophora & 0.164 & 0.667 & 0.1 & 1.333 & 0.172 & 0.8 & 0.147 & 0.364 & 0.238 & 0.308 \\
\hline H. incana & 0.617 & 0.606 & 0.909 & 1.282 & 2.5 & 2.5 & 0.819 & 0.667 & 0.714 & 0.5 \\
\hline H. pseudospeciosa & 0.625 & 0.625 & 0.819 & 0.833 & 0.455 & 0.5 & 0.714 & 0.345 & 0.625 & 0.263 \\
\hline
\end{tabular}

free radicals of extract of the species of lichen genus Heterodermia are evaluated and the data are presented in Table 3. The extract of all the lichen species showed consistent TEAC value from 12 to $13 \mathrm{mM}$ concentration. The TEAC value is expressed as the milimolar concentration of Trolox solution having an antioxidant equivalent to a $0.1 \%(\mathrm{w} / \mathrm{v})$ extract solution. This indicates higher the TEAC value of the sample, the stronger the antioxidant activity. As far as DPPH radical scavenging by the lichen extract is concerned only $H$. psedospeciosa showed nearly $52 \%$ scavenging of radical with $100 \mu \mathrm{l}$ of $1 \mathrm{mg}$ extract/ml in assay system. However other species showed $22 \%$ to $44 \%$ scavenging of radicals at same concentration of extract. The result on the basis of TEAC indicates that all the species have antioxidant potential.

Antimicrobial effects of the extract of species of lichen genus Heterodermia was determined and the data are presented in Table 5. The microbes B. subtillis, C. albidus and C. albicans were found to be very sensitive to the extract of lichen species $H$. diademata with lower MIC $0.232 \mathrm{mg} /$ $\mathrm{ml}$; . angustiloba with MIC $0.267 \mathrm{mg} / \mathrm{ml} ; H$. albicans with $0.514 \mathrm{mg} / \mathrm{ml}$; H. isidiophora with MIC $0.591 \mathrm{mg} / \mathrm{ml}$; H. flabellata with MIC $2.670 \mathrm{mg} / \mathrm{ml}$; H. antillarum with $3.944 \mathrm{mg} /$ ml. Only $H$. incana and $H$. pseudospeciosa had shown effects on $S$. faecalis with MIC $1.624 \mathrm{mg} / \mathrm{ml}$ and $3.246 \mathrm{mg} / \mathrm{ml}$ respectively. On comparing with the MIC value of standard antibiotics Streptomycin, Erythromycin and Tetracycline, it was found that lichen extract activity against the bacteria and fungus is higher.

Table 5. Minimum Inhibitory Concentration (MIC) values of the lichen species of the genus Heterodermia and the MIC value of standard antibiotics Streptomycin, Erythromycin, Tetracyclin against bacterial strain

\begin{tabular}{lclccc}
\hline Lichen species & $\begin{array}{c}\text { Extract } \\
\text { (mg/ml) }\end{array}$ & Bacterial & strain & \multicolumn{2}{c}{ Standard antibiotics $(\boldsymbol{\mu g} / \mathbf{m l})$} \\
\cline { 4 - 5 } H. diademata & 0.232 & B. subtills & Erythromycin & Tetracyclin & Streptomycin \\
\cline { 4 - 5 } H. angustiloba & 0.267 & C. albicans & 5.16 & 5.17 & 5.21 \\
H. albicans & 0.514 & C. albidus & 5.11 & 5.32 & 7.37 \\
H. flabellata & 2.670 & B. subtills & 5.29 & 5.13 & 5.15 \\
H. antillarum & 3.944 & C. albicans & 5.34 & 5.33 & 5.47 \\
H. isidiophora & 0.591 & C. albicans & 5.24 & 5.36 & 6.71 \\
H. incana & 1.624 & S. faecalis & 5.6 & 5.74 & 6.12 \\
H. pseudospeciosa & 3.246 & S. faecalis & 5.6 & 5.67 & 7.51 \\
\hline
\end{tabular}

Traditional use of lichens has clues to unknown potential novel drug molecules in the form of secondary metabolites. Many lichen extract or their isolated secondary metabolites have been recorded by many authors for various biological activities (Muller 2001, Rankovic 2007, Molnar \& Farska 2010, Shah 2014).

LOX inhibition by the species under different concentration of the extract, only two species $H$. diademata and H. albicans showed from $77 \%$ to $87 \%$ inhibition of LOX at higher concentration of extract $120-200 \mu \mathrm{g} / \mathrm{ml}$ with $\mathrm{IC}_{50}$ values 0.123 and $0.187 \mathrm{mg} / \mathrm{ml}$. Whereas $H$. flabellata, $H$. antillarum and $H$. incana showed $39 \%$ to $66 \%$ at the same concentration with $\mathrm{IC}_{50}$ from 0.15 to $0.16 \mathrm{mg} / \mathrm{ml}$. $\mathrm{IC}_{50}$ value of standard antioxidant BHA, BHT 0.198, $0.186 \mathrm{mg} / \mathrm{ml}$ showed $50 \%$ LOX inhibition was found to be more or less equivalent than the $\mathrm{IC}_{50}$ for LOX inhibition by seven species except $H$. diademata $\left(\mathrm{IC}_{50} 0.123 \mathrm{mg} / \mathrm{ml}\right)$. Our results are in agreement with those reported antioxidants such as BHA and BHT, which acts as free radical quenchers, may also act as LOX inhibitors (Zhou et al. 2005, Banerjee 2006).

The inhibition kinetics of the reaction by the species extract analysed by Lineweaver-Burk plot revealed that $H$. albicans showed competitive inhibition towards LOX. $H$. antillarum, $H$. diademata showed uncompetitive inhibition. H. angustiloba, H. flabellata, H. incana, H. isidiophora, H. psendospeciosa showed non competitive inhibition. The differential mode of lipoxygenase inhibition might be attributed to the inconsistent $\mathrm{Km}$ and Vmax obtained are because of increasing substrate concentration with respect to the species extract concentration that resulted differential intercept with different slopes. Furthermore, it was also observed that beyond $30 \mu \mathrm{g}$ extract per $\mathrm{ml}$, it acts as antagonistic effects on lipoxygenase inhibition.

The result of antibacterial effects of species extract revealed on the basis of MIC value, the bacteria B. subtilis, $C$. albidus and C. albicans are sensitive to the extract of $H$. diademata, $H$. angustiloba, $H$. albicans and $H$. isidiophora with concentration ranging from $0.232 \mathrm{mg} / \mathrm{ml}$ to $0.591 \mathrm{mg} / \mathrm{ml}$. 
Other species, H. flabellata and H. antillarum, showed no inhibition or showed $\leq 1 \mathrm{~cm}$ zone of inhibition. $H$. incana and $H$. psendospeciosa showed effects on $S$. faecalis with zone of inhibition of $\leq 2.5 \mathrm{~cm}$ with an MIC value $1.624 \mathrm{mg} / \mathrm{ml}$ and $3.246 \mathrm{mg} / \mathrm{ml}$ respectively. On comparing the potential of studied lichen species extract against tested microorganisms revealed that the MIC value of the extract was found to be very high than the standard antibiotics. Our results are in agreement with the Rankovic et al. (2007a, b) who reported that the bacterial inhibition can vary within the lichen extract, solvent used for extraction and bacteria tested.

\section{CONCLUSION}

The selected lichen species of Heterodermia genus had shown very mild to moderate activity in LOX inhibition, radical scavenging and antimicrobial activity. The crude extract of the species undertaken for the study contains lichen substances along with other accessory pigments. In this study at present, it is difficult to say which component of the extract had contributed towards the particular biological activities. In order to know lipoxygenase inhibition, radical scavenging and antimicrobial activity potential of the species, further studies would require to isolate and purification of the lichen substances possesses by the species should be tested. Probably this could explain the mode of action of the activities and usefulness of the lichen species and their metabolites for the use in pharmaceutics or may confirm its traditional use for several ailments.

\section{ACKNOWLEDGEMENTS}

We are very grateful to the Department of Biotechnology, Government of India, New Delhi, for financial support. We are thankful to Dr. B.O. Sharma, Mycology Group, for helping in taxonomic identification of lichen species. We are thankful to Director, Agharkar Research Institute, Pune for providing research facilities.

\section{LITERATURE CITED}

Baladrin, M.F., J.A. Klocke \& E.S. Wurtele 1985. Natural plant chemicals: sources of industrial and medicinal plants. Science. 228:1154-1160.

Barlow, S.M. 1990. Toxicological aspects of antioxidants used as food additives. In: Food Antioxidants (Hudson, B.J.F. ed.), pp. 253-308, Elsevier Applied Science, London, UK.

Behera, B.C., N. Verma, A. Sonone \& U.V. Makhija. 2005a. Antioxidant and antimicrobial activities of lichen Usnea ghattensis in-vitro. Biotechnology Letters 27:991-995.

Behera, B.C., N. Verma, A. Sonone \& U.V. Makhija 2005b. Evaluation of antioxidant potential of the cultured mycobiont of a lichen Usnea ghattensis. Phytotherapy Research 19:58-64.

Behera, B.C., N.D. Mahadik \& M.V. Morey 2012. Antioxidative and cardiovascular-protective activities of metabolite usnic acid and psoromic acid produced by lichen species Usnea complanata under submerged fermentation. Pharmaceutical Biology 50:968-979.

Blois, M.S. 1958. Antioxidant determinations by the use of a stable free radical. Nature 26: 1199-1200.

Conner, D.E. 1993. Naturally occurring compounds. In: Antimicrobials in foods. 2nd ed. (Davidson, P.M. \& A.L. Branen, eds.), pp. 441-468, Marcel Dekker Inc, New York.
Crittenden, P.D. \& N. Porter 1991. Lichen forming fungi: Potential sources of novel metabolites. Trends in Biotechno$\log y$ 9:409-414.

Culberson, C.F. \& H.D. Kristinsson 1972. A standardized method for the identification of lichen products. Journal of Chromatography 45:85-93.

Gaikwad, S.B., N. Verma, B.O. Sharma \& B.C. Behera 2014. Growth promoting effects of some lichen metabolites on probiotic bacteria. Journal of Food Science and Technology 51(10):2624-2631.

Govindappa, M., T.S. Sadanand, R. Channabasava \& V.B. Raghavendra 2011. In vitro antiinflammatory, lipoxygenase, xanthine oxidase and acetylcholinesterase inhibitory activity of Tecoma stans (L.) Juss. ex Kunth. International Journal of Pharma and Biosciences 2(2):275-285.

Iassonova, D.R., L.A. Johnson, E.G. Hammond \& S.E. Beattie. 2009. Evidence of an enzymatic source of off flavors in "lipoxygenase-null" soybeans. Journal of the American Oil Chemists' Society 86(1):59-64.

Kelavkar, U.P., C. Cohen, H. Kamitani, T.E. Eling \& K.F. Badr 2000. Concordant induction of 15-lipoxygenase-1 and mutant p53 expression in human prostate adenocarcinoma: correlation with gleason staging. Carcinogenesis 21(10):1777-1787.

Kelavkar, U.P., J.B. Nixon, C. Cohen, D. Dillehay, T.E. Eling \& K.F. Badr 2001. Overexpression of 15-lipoxygenase-1 in PC-3 human prostate cancer cells increases tumorigenesis. Carcinogenesis 22(11):1765-1773.

Mahadik, N.D., M.V. Morey, B.C. Behera, U.V. Makhija \& D.G. Naik 2011. Cardiovascular-protective, and antimicrobial properties of natural thallus of lichen Usnea complanata. Latin American Journal of Pharmacy 30: 220-228.

Manojlović N., B. Ranković, M. Kosanić, P. Vasiljevićc, T. Stanojković 2012. Chemical composition of three Parmelia lichens and antioxidant, antimicrobial and cytotoxic activities of some their major metabolites. Phytomedicine 19: 1166-1172.

Miller, N.J., A.T. Diplock, C.A. Rice-Evans 1995. Evaluation of the total antioxidant as a marker of the deterioration of apple juice on storage. Journal of Agricultural and Food Chemistry 43: 1794-1801.

Mitrović, T., S. Stamenković, V. Cvetković, M. Nikolić, S. Tošić, D. Stojičić 2011. Lichens as source of versatile bioactive compounds. Biologica Nyssana 2:1-6.

Molnar, K. \& E. Farkas. 2010. Current results on biological activities of lichen secondary metabolites: a review. Journal of Biosciences 65:157-173.

Muller, K. 2001. Pharmaceutically relevant metabolites from lichens. Applied Microbiology and Biotechnology 56:9-16.

National Committee for Clinical Laboratory Standards. 1993. Performance Standards for antimicrobial disk susceptibility test. M2-A5. Approved Standard NCCLS Publication, Vilionova, PA, USA.

Rackova L., M. Oblozinsky, D. Kostalova, V. Kettmann \& L. Bezakova 2007. Free radical scavenging activity and lipoxygenase inhibition of Mabonia aquifolium extract and isoquinoline alkaloids. Journal of Inflammation 4:15-21.

Ranković, B., M. Mišić \& S. Sukdolak 2007a. Antimicrobial activity of the lichens Cladonia furcata, Parmelia caperata, Parmelia pertusa, Hypogymnia physodes and Umbilicaria polyphylla. British Journal of Biomedical Science 64:143-148.

Ranković, B., M. Mišić \& S. Sukdolak 2007b. Evaluation of antimicrobial activity of the lichens Lasallia pustulata, Parmelia sulcata, Umbilicaria crustulosa and Umbilicaria cylindrica. Microbiology 76:723-727.

Serpen, A. \& V. Gokmen. 2007. Effect of $\beta$-carotene on 
soybean lipoxygenase activity: kinetic studies. European Food Research and Technology 224:743-748.

Shah, N.C. 2014. Lichens of commercial importance in India. The Scitech Journal 1(2):32-36.

Shinde, U.A., K.R. Kulkarni, A.S. Phadke, A.M. Nair, A.A. Mungantiwar, V.J. Dikshit \& M.N. Saraf 1999. Mast cell stabilizing and lipoxygenase inhibitory activity of Cedrus deodara (Roxb.) Loud. wood oil. Indian Journal of Experimental Biology 37:258-261.

Sircar, J.C., C.F. Schwende \& E.A. Johnson 1983. Soybean lipoxygenase inhibition by nonsteroidal anti-inflammatory drugs. Prostaglandins 25:393-396.

Stocker-Worgotter, E. 2008. Metabolic diversity of lichen forming ascomycetous fungi: culturing, polyketide and shikimate metabolite production and PKS genes. Natural Product Reports 25:188-200.

Taylor, T.N., H. Hass, W. Remy \& H. Kerp. 1995. The oldest fossil lichen. Nature 378: 244.

Theerakulkait, C. \& D.M. Barrett 1995. Lipoxygenase in sweet corn germ: isolation and physicochemical properties. Journal of Food Science 60:1029-1033.

Verma, N., B.C. Behera \& B.O. Sharma 2012. Glucosidase inhibitory and radical scavenging properties of lichen metabolites Salazinic Acid, Sekikaic Acid and Usnic Acid. Hacettepe Journal of Biology and Chemistry 40(1):7-21.

Verma, N., B.C. Behera, H. Parizadeh \& B.O. Sharma 2011. Bactericidal activity of some lichen secondary compounds of Cladonia ochrochlora, Parmotrema nilgeherrensis and Parmotrema sancti-angelii. International Journal of Drug Development and Research 3:222-232.

Verma, N., B.C. Behera \& U.V. Makhija 2008. Antioxidant and hepatoprotective activity of a lichen Usnea ghattensis in vitro. Applied Biochemistry and Biotechnology 151:167-181.

Zhou, B., A. Miao, L. Yang \& Z. Liu. 2005. Antioxidative effects of flavonols and their glycosides against the free-radical induced peroxidation of linoleic acid in solution and in micelles. Chemistry - A European Journal 11:680-691.. 